\title{
The Educational Use of Film and Television Documentary: Sugihara, Conspiracy of Kindness
}

\author{
William W. Bostock ${ }^{1, *}$ \\ ${ }^{1}$ School of Social Sciences, University of Tasmania, Hobart, Tasmania, Australia \\ *Correspondence: School of Social Sciences, University of Tasmania, Private Bag 22, GPO, Hobart, Tasmania 7005, \\ Australia. Tel: 61-3-6226-7453. E-mail: bostock@utas.edu.au
}

Received: July 19, 2017

doi:10.5430/jct.v6n2p13
Accepted: July 31, 2017 Online Published: August 20, 2017

URL: https://doi.org/10.5430/jct.v6n2p13

\begin{abstract}
Film or television documentary can serve a unique role in the curriculum and teaching of courses in political science and history where the complexity of the human element such as interaction, motive, identity and ethical position require analysis. The documentary Sugihara, Conspiracy of Kindness, a film by Kirk and Vicari, first screened on May 5,2005 on PBS, can in a qualitative sense positively demonstrate this role. The negative side to the use of film and television documentary is also noted.
\end{abstract}

Keywords: political science methodology; film; television documentary; Chiune Sugihara

\section{Introduction}

Teaching political science and history faces large challenges in reconciling the aims of freedom and equality while maintaining social cohesion (Fernndez-Soria, 2013). It is therefore worthwhile to examine the role of an individual faced in an historical context with the most extreme threat to cohesion. The limitation of traditional political science in addressing these contemporary issues has been pointed out and the need for an innovative approach established (Murphy, 2014). The value of multidisciplinary approaches, the use of non-classroom environments, study trips, simulation, and student-student interaction have all been recognized (Bostock, 1999) (Bostock, 2008) (Murphy, 2014). In addition to these techniques, film and television documentary have some huge advantages in that they can transport students across barriers of time and space without leaving the safety and comfort of the classroom (Yow, 2014).

In regard to political science, film and television documentary can demonstrate to students, in a very realistic way, the ever-present dichotomy between agency and structure, as shown for example in the fictional program The West Wing (Mobley and Fisher, 2015). In the case of Chiune Sugihara, now a famous Japanese diplomatic figure in World War II history, it will be seen that his role as an agent of saving peoples' lives took place within a very powerful multi-structure of Imperial Japanese foreign policy administration and Nazi ethno-racial policy. This dichotomy must have added to it the ethical dimension, to which the political agent may or may not respond, and which the political science traditional approach can only take as a given (Mobley and Fisher, 2015).

Film and television documentary can analyse further the question of agency. An examination of Kubrick's film The Shining requires the use of insights from psychoanalysis to explain how cognitive distortion can affect the minds of hitherto tranquil and peaceful persons who can then commit "reactive violence' (Merced, 2017). Psychoanalysis provides a representation of personality and psychology that can integrate extraordinary and uncommon experiences in the process by which the human brain reconciles competing motivations, as demonstrated in education by the presentation of this film (Merced, 2017).

So far, the positive benefits of the educational use of film and television have been discussed, but the negative side needs acknowledgement. The mental health of a student population cannot be taken for granted and vulnerabilities and sensitivities must be considered before a film or television presentation can be made. There are no definitive guidelines here other than experience, intuition and an ever-ready immediate response to informal feedback on the part of the instructor who must judge the appropriateness of the item (Berk,2009) (Bostock, 2003). As an aside, it is interesting to note that the eminent British military historian Sir Anthony Beevor observed that he could not watch films depicting military history as they all suffered from serious factual inaccuracy (Gore-Langton, 2017). 
Among other serious constraints is the risk of oversimplification. It has been pointed out, for example, that in teaching the place of African-Americans in American history, the complex idea that many in the North were simultaneously anti-slavery and anti-Black can be overlooked (Stoddart and Marcus, 2006). Further evidence of the risk of oversimplification is provided by an investigation of pathological gambling. While the film The Gambler gave a good perspective on pathological gambling and its effect on people, it did not establish for at least one student cohort that there was more than one reason to explain why people gamble to excess (Griffiths, 2004).

Another constraint is that students can have widely different intellectual responses to visual presentations, quite apart from the emotional and psychological responses referred to earlier. The fact that some students will be much more advanced in personal maturity than others in a class can present a challenge (Holland, 2014). With fictional presentations, some students found programs such as The West Wing to be more compelling than real life television news reporting, and for that matter, traditional political science instruction (Journell and Buchanan, 2013).

Constraints notwithstanding, the use of film and documentary in the context of teaching politics and history can provide a unique bridge between political science, psychology and historical narrative, through bringing to the center the sense of identity both at individual level and collective level or "...how power operates within the realm of the cultural and how social relations and identities are formed." (Giroux, 2011), (p.693).

In addition, film and television documentary have unique features which make them a powerful teaching tool (Champoux, 1999). Specifically, it can be noted that film and television documentary record reality in a fashion that is different from common human experience. By using a close up, the camera can capture the viewer's attention, while by using the shot/reverse shot technique, it can present personal interaction from a different perspective. By using non-verbal indicators such as the close up focussed on eye movement or facial expression, it can lead the viewer towards a new sense of meaning. If the camera shot is backed with carefully chosen music, the result can have considerable effect, as film and television documentary can employ both hemispheres of the viewer's brain: the left for deductive tasks and the right for intuitive tasks (Champoux, 1999).

\section{The Television Documentary Sugihara, Conspiracy of Kindness}

The television documentary Sugihara, Conspiracy of Kindness, a film by Kirk and Vicari, first screened on television on May 5, 2005 on PBS, was later shown and discussed as part of a course in a Second and Third Year at an Australian university in the late 2000's.

The documentary presents the life of Chiune Sugihara $(1900$ - 1986) with particular focus on his time as a Japanese diplomat who served as Vice Consul for Japan in Lithuania from 1939 to 1940. After the occupation of Lithuania by Nazi Germany's then ally, the Soviet Union, he assisted as many as ten thousand men, women and children facing deportation and death to leave occupied Europe by granting exit visas to refugees that enabled them to travel to Japan with an ultimate destination of Curaçao. These destinations were chosen because they did not require a visa. In this action he was helped by the Dutch Consul in Kaunas, Jan Zwartendijk. The majority of the people who escaped in this way were Jewish refugees fleeing Poland or citizens of Lithuania.

The television documentary establishes that Sugihara was born into a middle-class family in Yaotsu, a rural area in the Chūbu region, the second child among five boys and one girl. In 1912, he graduated with honors from Furuwatari School and entered Nagoya Daigo Chugaku (now Zuiryo High School), a combined junior and senior high school. The expectation of his father was that Chiune would follow his own career as a physician, but he failed the entrance examination, possibly deliberately, and instead majored in English literature. He then studied languages and literature at Waseda University. In 1919, he successfully completed the Foreign Ministry Scholarship entry examination. Following his recruitment to the Japanese Foreign Ministry he was posted to Harbin, China, where he continued his language studies, this time with Russian and German, making himself an expert on Russian affairs.

After Japan's conquest and occupation of Manchuria, (which they renamed Manchukuo), Sugihara was seconded to the Foreign Office branch office in Manchuria, where he took part in the complicated negotiations with the Soviet Union concerning the building of a railroad across Northern Manchuria. In an early display of his humanitarian concern, Sugihara resigned from his position as Deputy Foreign Minister in Manchuria in protest over Japanese mistreatment of the local Chinese. While in Harbin, he converted to Orthodox Christianity and married a Russian woman, whom he later divorced. After returning to Japan, he remarried, this time to Yukiko Kikuchi with whom he had four sons. The marriage was unusual for Japanese culture at that time in that Sugihara considered his wife as an equal. After returning to Japan, Sugihara worked in the Information Department of the Ministry of Foreign Affairs. He was then posted abroad again, this time to Helsinki, Finland, where he worked for the Japanese legation as a translator. 
In 1939, he was appointed Vice-Consul in the Japanese Consulate in Kaunas, which at that time was capital of Lithuania. He also had responsibility also for observing and reporting on Soviet and German troop movements.

When the Soviet Union took over Lithuania in 1940, many Jewish refugees from Poland as well as Lithuanian Jews desperately tried to obtain acquire exit visas. Without the visas, it was impossible to find countries willing to accept them. Hundreds of refugees came to the Japanese consulate in Kaunas to try to obtain a visa to Japan. Word had gotten out that the Dutch consul, Jan Zwartendijk, had provided some of them with an official third destination to Curaçao, a Caribbean island under Dutch control or Dutch Guyana (nowadays Suriname), that did not require entry visas.

The Japanese government at that time followed a more or less officially neutral policy towards the Jews but in practice, discriminated against Jews by demanding that visas be issued only to those with appropriate visas and in possession of enough funds. Most of the refugees presenting themselves at the Japanese Consulate in Kaunas did not fulfil these criteria. Sugihara dutifully contacted his Foreign Ministry three times for instructions. On each occasion, the Ministry responded that to be granted a visa, an applicant should have, with no exception, a visa to a third destination in order for them to exit Japan.

Between July 31 to August 28, 1940, after consulting with his family, Sugihara commenced granting visas on his own initiative in contravention of the official guidelines. In violation of these orders, he provided the people he assisted with ten-day visas to transit through Japan. In view of his position and the prevailing modus-operandi of the Japanese Foreign Service, this was an unprecedented action. He obtained from Soviet officials an agreement to allow the Jews to travel across Russia by the Trans-Siberian railway, though at a cost five times the normal ticket price.

Sugihara continued to produce visas until September 4, when he had to leave his position as the consulate was closed. By this time, he had granted thousands of visas to Jews, many of them as family visas. As he was leaving Kaunas, Sugihara was reported to be still writing visas while in transit. Sugihara himself wondered about official reaction to the thousands of visas he issued. Many years later, he recalled that no one ever said anything about it as they probably didn't realize how many had been issued.

The television documentary Sugihara, Conspiracy of Kindness states that the total number of Jews saved by Sugihara ranged from 6,000 to 10,000 , and notes that many of the visas issued were family visas which allowed several people to travel on the one document. It was noted that some Jews who received Sugihara visas failed to exit Lithuania in time and were later captured by the Germans who invaded their hitherto ally the Soviet Union on June 22, 1941 (without giving prior notice to their then-other ally Japan), and perished in the Holocaust.

Most of the refugees with visas provided by Sugihara were able to travel across the Soviet Union to Vladivostok and then by boat to Kobe, Japan, where there was an established Russian Jewish community. From there, a small proportion were able to depart for other destinations such as the United States and the British Mandate of Palestine. The remaining number of Sugihara/Zwartendijk survivors stayed in Japan until they were deported to Japanese-held Shanghai, where they were able to join the substantial Jewish community.

In the television documentary, it is noted that despite German pressure for the Japanese government to either hand over or kill the Jewish refugees, the government did largely protect these people. In an interview in the documentary, writer and rabbi Marvin Tokayer, asserts that Japanese tolerance of Jews was influenced by a sense of gratitude for a $\$ 196$ million loan that a Jewish banker from New York, Jacob Schiff, had granted to Japan, at a time when European bankers had denied any loans, funds that Japan had sought to finance their war with Russia in 1905. Another theme was provided by prevailing idea of the 1930s of the supposed economic skills of Jews (partly as some Japanese leaders had read anti-Semitic tracts, such as the bogus Zinoviev Papers, attributing extraordinary wealth and power to Jews), which consequently made Jewish resettlement a desirable policy aim for the Japanese empire. The Japanese were, at this time, specifically desirous to populate Manchukuo and saw European Jewish refugees as suitable future settlers. Finally, it is suggested in the documentary that Jewish leaders of that time pointed out to important members of the Japanese government that, notwithstanding the signing of the Tripartite Pact between Germany, Italy and Japan in 1940 and later similarity of Tripartite Axis war aims, there was a similarity of ethno-racial identity between Asians and Jews, as the latter may have had Asian origins. Therefore, the Japanese leadership came to believe that both groups, the Jews and the Japanese, were devalued in the Nazi ethno-racial hierarchical thinking.

In 1947, two years after the end of World War II, the Japanese Foreign Office made Sugihara resign, officially due to downsizing. Some sources, including his wife, have stated that the Foreign Ministry made Sugihara resign because of "the incident" in Lithuania. In October 1991, the ministry told Sugihara's family that Sugihara's resignation was part of a reorganization of personnel. On March 24, 2006, the Foreign Ministry issued a position paper that stated that there was no evidence the Ministry imposed disciplinary action on Sugihara. The Ministry stated that Sugihara was one of 
many officials to resign voluntarily, but that it was difficult to confirm the details of his individual resignation. In the report, the Ministry praised Sugihara's conduct, calling it a courageous and humanitarian decision.

The documentary notes that later Sugihara settled in Fujisawa and was employed as General Manager of a U.S. Military Post Exchange. Sugihara then went to work and live a low-key existence in the Soviet Union for sixteen years, using his knowledge of the Russian language, while his family stayed in Japan.

In 1968, Jehoshua Nishri, an economic attaché at the Israeli Embassy in Tokyo and himself a Holocaust survivor owing his life to Sugihara, finally located and contacted him. In 1969, Sugihara visited Israel where he was officially received by the Israeli government. In 1985, Chiune Sugihara's achievements were recognized with the granting of the honor of membership of the Righteous Among the Nations, an official Israeli order. The same year, 45 years after the Soviet invasion of Lithuania, Sugihara was asked his reasons for issuing visas to the Jews. Sugihara gave two reasons: one, that these refugees were human beings, and the other, that they simply needed help. When asked why he risked his career to save other people, he referred to an old samurai saying that even a hunter cannot kill a bird which flies to him for refuge.

The following year, Sugihara died. In spite of the publicity given him in Israel and other nations, he remained largely unknown in Japan. Only when a large Jewish delegation from around the world, including the Israeli Ambassador to Japan, attended his funeral did his community became aware of his achievement.

Today there is a Sugihara Street in Kaunas and one in Vilnius, Lithuania, and the asteroid 25893 Sugihara is named after him. The Chiune Sugihara Memorial in the town of Yaotsu (his birthplace) was built by the people of the town in his honor.

\section{A Suggested Two-Hour Session Plan}

Well before the actual session, students should be given and urged to carry out preparatory reading of selected references, such as Tokayer and Swartz (1979), Levine (1996) and Shlensky (2003).

The actual session should begin with a formal lecture style presentation giving a brief review of the life of Sugihara, the historical context of the structures within which he operated, and his achievements. Particular attention could be drawn to these questions

1. To what extent is it possible to act within freedom in seeking to grant people equality in the context of the high levels of cohesion required in wartime?

2. In what specific ways do the structures of government impinge upon the individual agent?

3. Is there a place for an ethical dimension when acting within the constraints of a diplomatic posting?

4. Can the psychology of identity give any insight into the unconventional and illegal actions of Sugihara?

5. How can the difference of ethno-racial policy between Nazi Germany and Imperial Japan be explained?

After the screening of the documentary, the same questions can be posed, and in the time remaining, as this will test the teacher's intuitive assessment as to whether the documentary was appropriate to a particular student constituency. Where appropriate, analysis and participatory discussion can follow, either as a whole class activity or in groups. Further follow up would consist of essay topics and examination questions. From the teacher's perspective, there could be quantitative survey of student satisfaction.

\section{Conclusion}

Film or television documentary can thus offer a unique place in in the curriculum and teaching of courses in political science and history, and the use of the documentary Sugihara, Conspiracy of Kindness can provide a relevant example. This is through the complex interplay between agency, structure, identity and ethical position, as shown in the actions of Chiune Sugihara.

The negative side to the use of film and television documentary, such as oversimplification, susceptibilities among the student constituency and widely divergent levels of prior historical knowledge and ability, must be carefully assessed and taken into account. However, when considered appropriate, the use of a particular film or television documentary can bring extraordinary benefit to curriculum and teaching. 


\section{References}

Berk, R. L. (2009). Multimedia Teaching with Video Clips: TV, Movies $<$ YouTube, and $m t v U$ in the College Classroom. International Journal of Teaching and Learning, 5(1), 1-21.

Bostock, C. S. (1999). Overcoming Anxiety: The Use of the Global Simulation Technique in the Teaching of French to Adults. Darwin: Northern Territory University. (Doctoral dissertation).

Bostock, W. W. (2003). Depression Among Students: a Challenge for Educational Leadership. International Journal of Humanities and Peace, 19(1), 50-52.

Bostock, W.W. (2008). Using Global Simulation to Study Ethnic Conflict. Academic Exchange Quarterly, 12(4), 192-196.

Champoux, J. E. (1999). Film as a Teaching Resource. Journal of Management Enquiry, 8(2), 206-217.

Fernández-Soria, J. M. (2013). Problemas y retos en la Poliítica de la Educación ante el cambio de protagonismo en los actores. New Approaches in Educational Research, 2(2), 63-71. https://doi.org/10.7821/naer.2.2.63-71

Giroux, H. A. (2011). Breaking into the Movies: public pedagogy and the politics of film. Policy Futures in Education, 9(6), 686-694. https://doi.org/10.2304/pfie.2011.9.6.686

Gore-Langton, R. (2017). Based on a true story or just a film fantasy? International Express, March 22, 35. (Newspaper).

Griffiths, M. D. (2004). An Empirical Analysis of the Film, The Gambler. ECommunity, International Journal of Mental Health \& Addiction, 1(2), 39-43.

Holland, J. (2014). Video Use and the Student Learning Experience in Politics and International Relations. Politics, 34(3), 263-274. https://doi.org/10.1111/1467-9256.12022

Journell, W., \& Brown Buchanan, L. (2012). Making Politics Palatable: Using Television Drama in High School Civics and Government Classes. The Social Studies, 103(1), 1-11. https://doi.org/10.1080/00377996.2011.571302

Kirk, R., \& Vicari, D. E. (2005). Sugihara, Conspiracy of Kindness. Boston: WGBH. (Documentary aired on PBS May $5,2005)$.

Levine, H. (1996). In Search of Sugihara. New York: Free Press.

Merced, M. (2017). How Narcissistic Injury May Contribute to Reactive Violence: A Case Example Using Stanley Kubrick's The Shining. International Journal of Applied Psychoanalytic Studies, 14(1), 81-96. https://doi.org/10.1002/aps.1484

Mobley, K., \& Fisher, S. (2015). A Field Guide to Teaching Agency and Ethics: The West Wing and American Foreign Policy. Dialogue: The Interdisciplinary Journal of Popular Culture and Pedagogy, 2(1), 1-32.

Murphy, M. (2014). The Future of European Studies: A Perspective from Ireland. Journal of Contemporary European Research, 10(4), 472-489.

Shlensky, J. (2003). Considering Other Choices: Chiune Sugihara's Rescue of Polish Jews. Hiroshima: Japan Studies Association Conference.

Stoddard, J. D., \& Marcus, A. S. (2006). The Burden of Historical Representation: Race, Freedom and Educational "Hollywood" Film. Film \& History: An Interdisciplinary Journal of Film and Television Studies, 36(1), 26-35. https://doi.org/10.1353/flm.2006.0018

Tokayer, M., \& Schwartz, M. (1979). The Fugu Plan. New York and London: Paddington Press.

Yow, D. M. (2014). Teaching Introductory Weather and Climate Using Popular Movies. Journal of Geoscience Education, 62, 118-125. https://doi.org/10.5408/13-014.1 